\title{
LEASING IN THE ROMANIAN THEORY AND PRACTICE
}

\author{
Valentin PÎRVUȚ \\ pirvut_v@yahoo.com \\ “NICOLAE BĂLCESCU” LAND FORCES ACADEMY, SIBIU, ROMANIA
}

\begin{abstract}
:
From the perspective of national economy, leasing represents a means of reorientating investments by attracting several new external financial sources in economy and a solution for launching on the market the products that have a limited demand and a low level of purchasing. Leasing represents an important factor in developing and making foreign trade more efficient through the possibility of entering on new markets and of opening new partnerships. Also, leasing attracts important financial resources since it has principal factors such as efficiency and safety.
\end{abstract}

\section{KEYWORDS:}

Leasing, financial leasing, operational leasing, financing, financier

\section{Introduction}

The practical interest of leasing is to ensure integral financing through borrowed funds for an investment without the beneficiary establishing precautionary measures; by doing this, leasing differentiates itself from the traditional credit investments where the recipient enterprise sustains a part of the value of the investment. Thus, as a financing technique, leasing has in view primarily the enterprises that aim at expanding the activity and raising performance, providing technical progress on a more general level. The term 'leasing' is unknown in Romanian, being taken over from the English economic and commercial jargon, where it was established a century ago, being then taken over by the Western European countries. We further propose to analyse from a theoretical viewpoint the concept of leasing, as well as its main characteristics.

\section{Generalities Regarding Leasing}

According to the Explanatory Dictionary of the Romanian language, the term "leasing" refers to "the operation in which a locator undertakes to buy or to take over a movable assset or a property from a supplier at the demand of a user and to transmit the user its possession or usage against a payment, called royalty, for the 
purpose of exploiting or acquiring it as is the case" (Romanian Academy, 1998).

According to the economic dictionary, the notion of leasing refers to "the technique of professional credit which supposes the conclusion of a lease of immovable property, equipment or other fixed assets for a determined period of time, against a tax established as a rule in the form of rent and is accompanied by a locator's promise of selling in favour of the tenant; in the case of financial leasing, the locator is confined only to financing the tenant with a view to purchasing the equipment, while in the case of operational leasing the locator cares for the maintenance, service and payment of insurance and taxes as well" (Angelescu, 2001).

The leasing contract - financial or operational - represents the "obligation of the locator/financier to provide the asset, having the liberty of choosing the insurer if the parties haven't agreed otherwise. The costs of insurance belong to the tenant/user if the parties do not agree otherwise in a provision of the contract" (Romanian Government, 1997).

The leasing contract is "an agreement through which the locator - the leasing company - transfers to the tenant/user the right to use an asset for an established period of time, in exchange of a payment or a series of payments" (Pântea and Bodea, 2007).

\section{FINANCIAL LEASING}

\section{OPERATIONAL} LEASING

The operational leasing is "an operation of successively renting an assset. The accumulated rental periods are normally shorter than the lifetime of the asset" (Constantinescu, 2006). usage over the financed asset, thus acting as a link between the supplier and the beneficiary of goods.

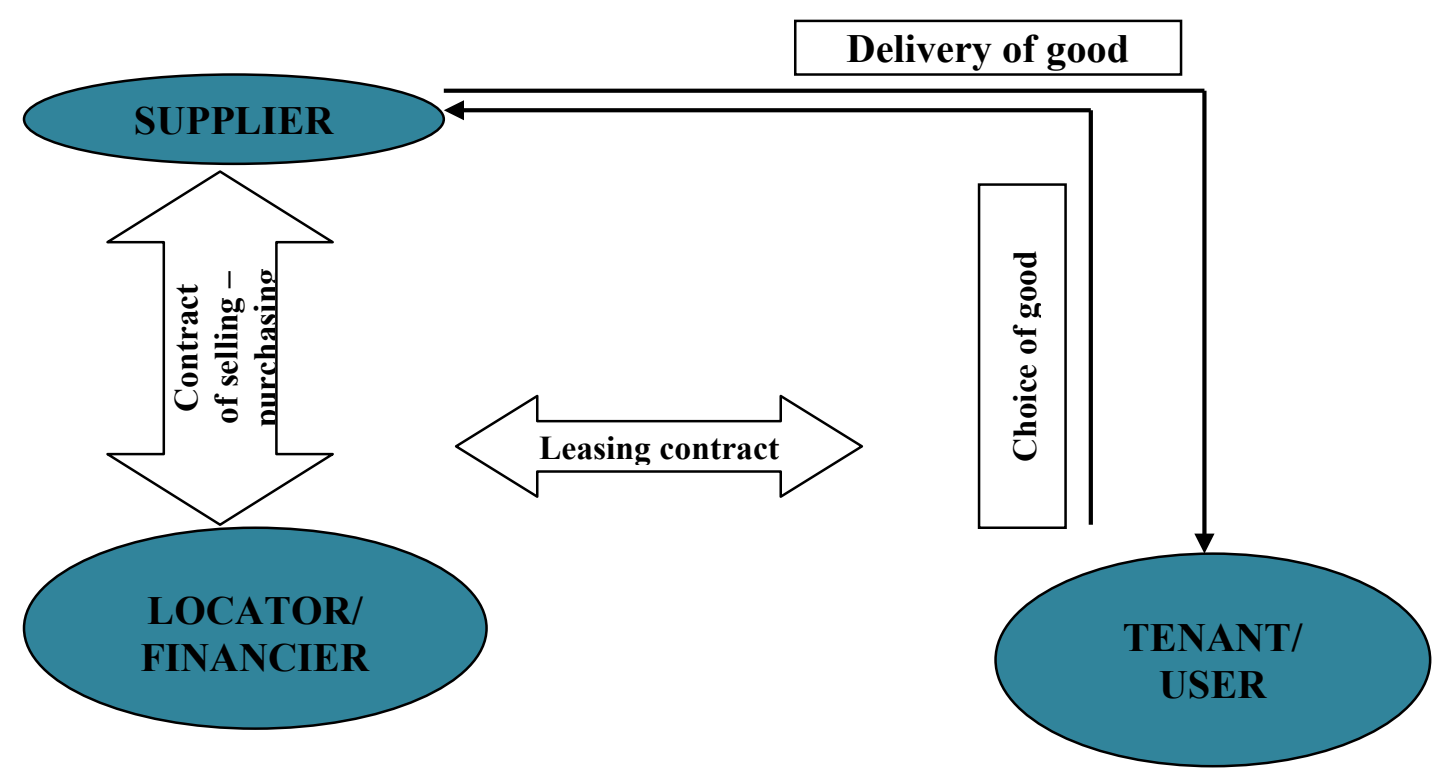

Figure no. 1. Operation of financial leasing 


\section{Characteristics of Leasing}

Through its complexity, the leasing oprration features certain specific characteristics, such as:

- The leasing operation is an operation of renting certain goods;

- The user's needs direct the acquisition of the good;

- The leasing operation is an intermediary operation.

According to the nature of the leasing contract, financial or operational, distinct characteristics are to be distinguished.

The contract of financial leasing has the following characteristics:

- "When the contract expires, the right of property over the good is transfered;

- The period of using the good covers at least $75 \%$ of its service life;

- The purchase by the tenant is done at the price of at most $50 \%$ of its market value;

- The lease rate is made up of the share of the asset value of the lease plus interest, which is comparable to the average rate of bank interest;

- The risks and rewards of ownership are transferred to the user from the time the contract is concluded" (Pântea \& Bodea, 2007).

The operational or exploitation lease contract features characteristics such as:

- The lease rate is made up of the share in the legally calculated depreciation plus a profit established through negotiation;

- "The depreciation is calculated by the financier, allowing for the depreciation of the whole value of the good minus the residual value - the value at which the transfer of the right of property over the good throughout the duration of the contract, but not less than 3 years" (Pântea \& Bodea, 2007).

\section{Advantages and Disadvantages of Leasing \\ The leasing operation has advantages and disadvantaages both for the beneficiary}

and for the financier and supplier. With regard to the beneficiary, there are the following advantages:

- The possibility of using your own capital for achieving other goals than the procurement of a good, the leasing operation not requiring an advance payment;

- The lease operation does not suppose supplementary guarantees;

- The user's need prevails and the user has the possibility of choosing the good, but the supplier's need as well;

- The possibility of negotiating the lease rates;

- Flexibility of the graph of payments (Constantinescu, 2006).

From the perspective of the financier, of the leasing company, there are the following advantages:

- Supplementary earnings;

- Guarantees for new loans by maintaining the right of property;

- High rates of return;

- Low procurement costs Constantinescu, 2006).

The supplier also benefits from advantages, such as:

- Promoting and developing exports;

- Attracting new users;

- Promoting goods;

- High rate of profit.

The disadvantages of leasing are as follows:

- The possibility of deterioration of goods;

- The high cost of transactions through the necessity of advisers and analysts;

- In the situation of the dissolution of the contract, difficulties arise in asset recovery;

- The lease rates are included in the deductible expenses and the tax is reduced, thus leading to erroneous choices in terms of the lease offers;

- The insurance costs in the case of financial leasing are included in the lease rate. 


\section{Structural Elements of Leasing}

Leasing operations

The leasing operations can be categorized "according to the financial or the non-financial nature, the degree of involvement of the supplier of goods in the leasing transaction, duration of the leasing contract, structure of the financed sum, the territorial criterion, and others" Constantinescu, 2006).

According to the financial or nonfinancial nature of leasing operations, we distinguish:

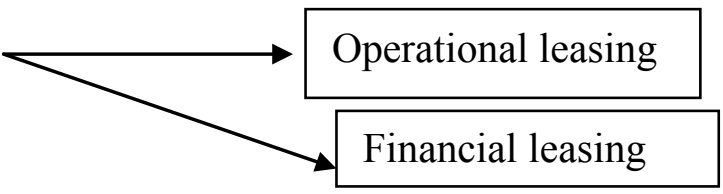

According to the criterion determined by the degree of involvement of the good suppliers in the leasing transaction, we distinguish:

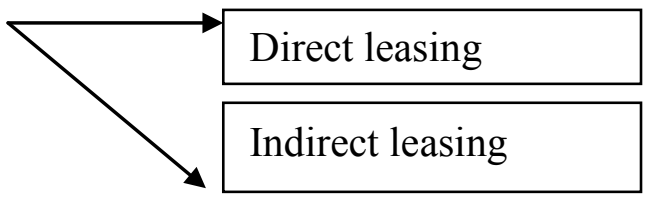

The leasing market features "special forms of leasing, determined by specific characteristics, such as: real estate leasing, master lease, sale and reintroduction of lease assets and lease-back-leasing projects, leasing provider" Constantinescu, 2006).

Object of the financial leasing contract

"The object of operations of leasing is immovable property by nature or which becomes immovable by destination, as well as movable, under the civil circuit, with the exception of recorded audio tape, theater plays, manuscripts, patents, rights' author and intangibles" (Romanian Government, 1997).

\section{The leasing operations}

Besides the contracting parties, the leasing contract must comprise at least the following elements:
- "The clause regarding the definition of the leasing contract as financial or operational leasing;

- Name of the good subject to the lease contract and the characteristics for its identification;

- The exact value of the sums of the monthly leasing rates and the exact date of payment;

- The period of using the good in a leasing system;

- The clause regarding the obligation of insuring the good;

- The total value of the leasing contract" (Romanian Government, 1997).

Besides the elements previously mentioned, the financial leasing contract must contain the following:

- "The entry value of the good;

- The residual value of the good established by the parties when is the case;

- The value of the advance payment;

- The leasing rate" (Romanian Government, 1997).

"The leasing contract is concluded in writing. When the leasing contract is terminated out of the user's guilt or through the total disappearance of the good by theft, total damage, complete distruction, defined according to the law, occurred before the first year of the contract entry into force, this does not change its nature and the good which is subject to the leasing contract is treated as a good in terms of tax and accounting, object of a leasing contract" (Romanian Government, 1997).

"The leasing contracts, as well as the real and personal guarantees, set up to guarantee the obligations assumed under the lease, are writs of execution" (Romanian Government, 1997).

The following chart highlights the characteristics of a financial leasing contract through the parallel between the financial and the operational leasing: 


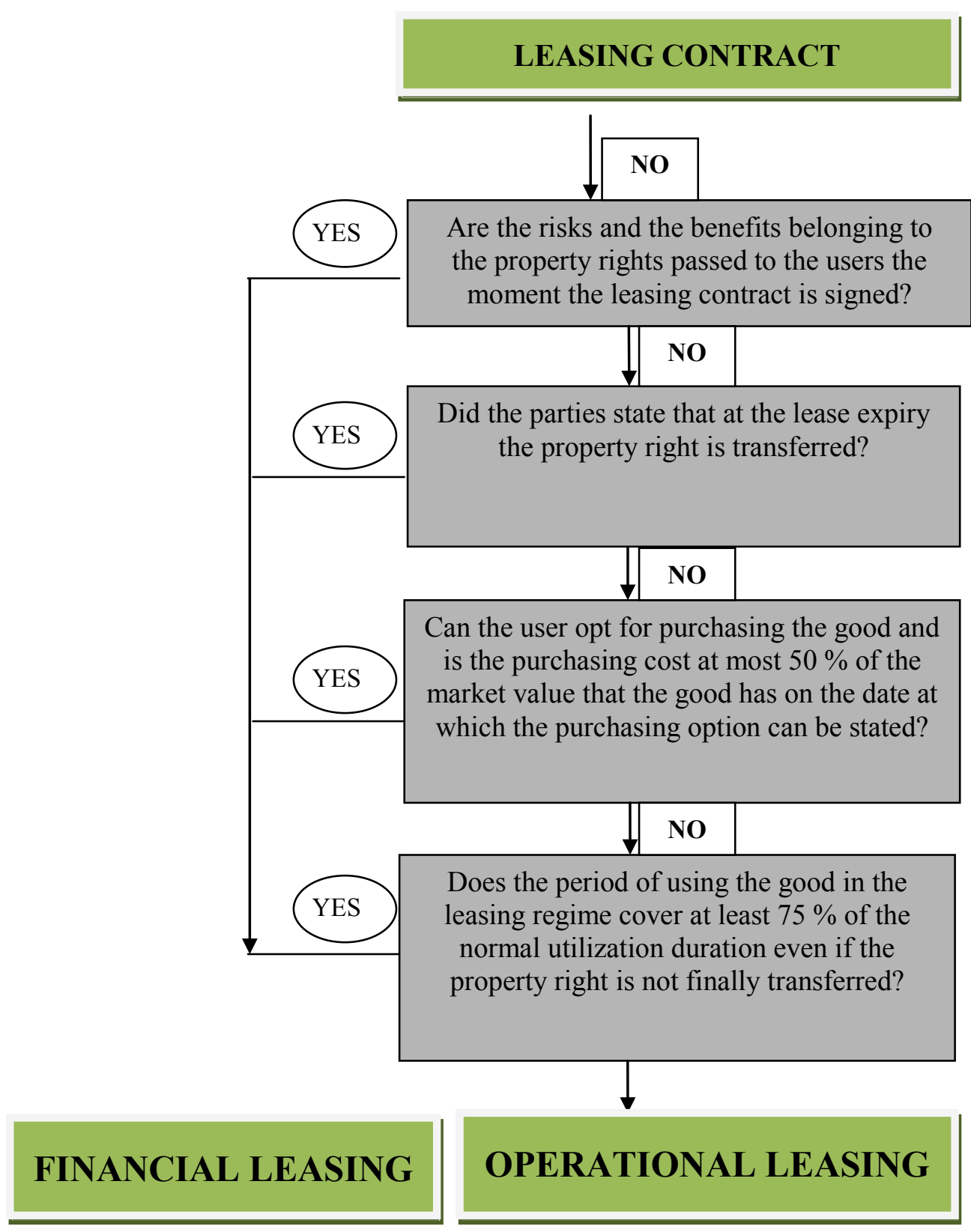

Figure no. 2. Parallel between the financial leasing characteristics and the operational leasing characteristics

\section{Conclusions}

The leasing represents a current issue, being used in the procedures of procuring tangible assets. At the same time it is extremely important through the correlation between leasing and the economy of the state, being considered a major market instrument. From the perspective of national economy, leasing represents a modality of reorienting investments by attracting new financing sources in economy and a solution for launching on the market the products that have a limited demand and a low level of purchasing. Leasing is an important factor in developing and making foreign trade efficient through entering new markets and closing new partnerships. Leasing also attracts major financial resources by defining principal factors such as profitability and safety. 


\section{REFERENCES}

Academia Română. (1998). Dicţionarul explicativ al limbii române (ediţia a II-a), Bucureşti: Editura Univers Enciclopedic.

Angelescu, C. (2001). Dicţionar de economie (ediţia a II-a), Bucureşti: Editura Economică.

Constantinescu, C.C. (2006). Leasing financiar: realitate şi perspectivă, Bucureşti: Editura Economică, 30.

Guvernul României. (1997). Ordonanţa nr. 51 din 28.08.1997 privind operaţiunile de leasing şi societăţile de leasing modificată şi actualizată, Capitolul I \& II, available at: http://www.brdleasing.ro/uploads/Docs/OG\%2051 1997.pdf, accessed at: 10.07.2016

Pântea. I.P. \& Bodea, Gh. (2007). Contabilitatea financiară românească conformă cu directivele europene - Editiia a II-a, Cluj-Napoca: Editura Intelcredo, 77. 